\section{Magnetic resonance imaging of the lung with a volumetric interpolated 3D-Gradient echo sequence}

Summary. Objective: To evaluate the feasibility of a magnetic resonance imaging protocol for the lung using a volumetric interpolated 3D-gradient echo sequence (3D-GRE). Subjects and Methods: $\mathrm{A} \mathrm{T}_{1}$-weighted $3 \mathrm{D}-\mathrm{GRE}$ sequence was used for volumetric interpolated breath-hold examinations ("VIBE") of the lung in twelve healthy volunteers (TR/TE 4.5/1.9 ms, flip-angle $12^{\circ}$, matrix $502 \times 512$ [interpolated]). Three coronal $80 \mathrm{~mm}$ slabs (16 partitions, $2.5 \mathrm{~mm}$ slices) were added to 3D data sets for multi-planar reformations. No contrast material was applied. Artifacts and resolution of vessel and airway structures in each lung segment were evaluated by two observers (12 volunteers, 228 lung segments). Results: The protocol provided excellent images of vascular and tracheo-bronchial structures with very moderate pulsation artifacts. 224/228 lung segments were imaged with "good" (146/228) or "sufficient" quality (78/ 228). Segmental and sub-segmental vessels ( $5^{\text {th }}$ order) were identified due to bright flow signal without administration of contrast material. Walls of segmental bronchi ( $3^{\text {rd }}$ order) were delineated in all parts of the lung. Conclusions: The high spatial resolution, the excellent visualization of lung anatomy, the low rate of artifacts without respiratory triggering and the short acquisition times are clear advantages of the 3D-GRE (VI$B E$ ) sequence compared to existing 2D-GRE strategies for MRI of the lung.

Key words: MRI - Lung - Volume interpolation - Breath-hold examination

Magnetresonanztomographie der Lunge mit einer volu-
meninterpolierten 3D-Gradientenechosequenz. Ziel: Bewer-
tung eines MRT-Sequenzprotokolls zur nativen Untersuchung
der Lunge mit einer volumeninterpolierten 3D-Gradienten-
echosequenz (3D-GRE). Methoden: 12 gesunde Probanden
wurden mit einer $\mathrm{T}_{1}$-gewichteten 3D-Gradientenechosequenz
(TR/TE 4,5/1,9 ms, Flip-Winkel $12^{\circ}$, Matrix $502 \times 512$ [interpo-
liert]) in Atemanhaltetechnik ohne Kontrastmittel untersucht
(volumetric interpolated breath-hold examination = "VIBE"). Je
drei koronare Schichtblöcke von 80 mm Dicke (16 Partitionen,
2,5 mm Schichtdicke) wurden zu dreidimensionalen Datensät-
zen der gesamten Lunge addiert. Detailauflösung und Arte-
fakte wurden semiquantitativ von 2 Untersuchern im Konsens
bewertet (12 Probanden, 228 Lungensegmente). Ergebnisse:
Das Untersuchungsprotokoll ergibt eine hervorragende Darstel-
lung der Lungengefäße und des Bronchialsystems. Bildartefakte

Fortschr Röntgenstr 2001; 173: $883-887$

(c) Georg Thieme Verlag Stuttgart · New York

ISSN 1438-9029
J. Biederer ${ }^{1}$, J. Graessner ${ }^{2}$, M. Heller ${ }^{1}$

${ }^{1}$ Klinik für Diagnostische Radiologie, Universitätsklinikum Kiel

2 Siemens Aktiengesellschaft, Hamburg durch Pulsation sind gering: 224/228 Lungensegmente wurden in guter oder unwesentlich beeinträchtigter Bildqualität erfasst (146/228 gut; 78/228 unw. beeintr.). Helles Flusssignal kennzeichnet segmentale und subsegmentale Gefäße 5. Ordnung auch ohne Kontrastmittelgabe. Wände von Segmentbronchien (3. Ordnung) werden in allen Lungenabschnitten dargestellt. Schlussfolgerungen: Hohe Detailauflösung mit hervorragender Darstellung der Lungenstruktur und geringen Artefakten auch unter Verzicht auf eine kardiale Triggerung bei kurzen Akquisitionszeiten kennzeichnen deutliche Vorteile volumeninterpolierter 3D-GRE (VIBE)-Sequenzen gegenüber der üblichen 2DGRE Technik.

Schlüsselwörter: MR-Tomographie - Lunge - Volumeninterpolation - Atemanhaltetechnik

\section{Introduction}

The unique anatomy of the lung with it's low proton density and strong susceptibility artifacts at air-tissue interfaces remains a fascinating challenge for the development of suitable magnetic resonance imaging (MRI) techniques [1]. Fast 2D Fourier transform gradient echo sequences (2D-GRE) with short TE were among the first applicable protocols for breathhold imaging. As a major disadvantage of 2D-GRE sequences, the use of very thin sections is limited by the reduction in signal to noise ratio [2-4]. The aim of this study was to create a lung MRI protocol using a $\mathrm{T}_{1}$-weighted three-dimensional fast Fourier transform gradient recalled echo sequence (3D-GRE) for volumetric interpolated breath-hold examination ("VIBE"). Compared to conventional 2D-GRE sequences, we expected a higher spatial resolution and a reduction of cardiac pulsation artifacts with the particular advantages of 3D-acquisitions, such as contiguous slices and reconstruction capabilities. We suggest a complete protocol for MRI of the lung with 3D-GRE (VIBE) at maximum spatial resolution and with coronal slice orientation.

\section{Subjects and Methods}

All studies were performed on a commercial 1.5 T MRI unit (Magnetom Vision, Siemens, Erlangen, Germany) with a maximum gradient strength of $25 \mathrm{mT} / \mathrm{m}$ and rise time of $600 \mu \mathrm{s}$.

Received: 10. 8.2001 Accepted after revision: 3. 9. 2001 
Twelve healthy volunteers ( $8 \mathrm{~m}, 4 \mathrm{f}$, average age 33,8 years, age range $18-64$ years) were examined with the body phased array coil. The requirements of the institutional review board were fulfilled and all volunteers gave their informed written consent for the study after being informed about the procedure. No contrast material was applied.

For imaging, we used a $\mathrm{T}_{1}$-weighted $3 \mathrm{D}$-GRE (VIBE) sequence with a repetition time (TR) of $4.5 \mathrm{~ms}$, an echo time (TE) of $1.9 \mathrm{~ms}$ and a flip angle of $12^{\circ}$. The technical features of the sequence structure were described in detail by Rofsky et al. [5] and in the manuals of the manufacturer (Siemens, Erlangen, Germany). Briefly, the 3D-GRE (VIBE) is a 3D radio-frequency-spoiled GRE sequence similar to sequences used for 3D-MR-angiograms, but with a reduced flip angle to enhance soft tissue contrast. The sequence uses symmetric echo in the read direction and partial in-plane Fourier sampling in the phase encoding direction. The matrix is interpolated in both directions resulting in images with a maximum in-plane resolution of $512 \times 512$ pixels. Acquisition time is further shortened by reducing the number of phase encoding steps along the partition direction with asymmetric echo sampling and sinc interpolation (zero filling) [5]. The sequence protocol also includes a quick fat saturation scheme with chemically selective fat-saturation pulses and optional cardiac triggering. The latter was not applied to the present series.

The rectangular field of view was adapted individually to each subject with sizes from 350 to $450 \mathrm{~mm}$ for images in coronal orientation. Slabs of $80 \mathrm{~mm}$ thickness with 16 partitions and an initial matrix of $251 \times 256(98 \%)$ were obtained within a scan time of $20 \mathrm{~s}$ or less (depending on the rectangular field of view). Two additional partitions provided $14 \%$ oversampling for elimination of mirroring artifacts. The effective slice thickness of $5 \mathrm{~mm}$ was reduced to $2.5 \mathrm{~mm}$ by volume interpolation. All images were displayed with an interpolated in-plane matrix of $502 \times 512$ pixels. For fat signal suppressed images, initial and interpolated matrices were reduced to $90 \%$ to keep within the time frame of a breath hold. The other parameters remained unchanged. Three coronal slabs were acquired to cover the lung completely. The first slab was centered on the mid-mediastinum and the tracheal bifurcation. Additional slabs were positioned anterior or posterior to this slab with at least $10 \mathrm{~mm}$ overlap. Numeric slab positioning in $2.5 \mathrm{~mm}$ steps permitted secondary reformations of the whole volume. All images were obtained in deep breath-hold. No respiratory or cardiac-triggering was applied.

The presence of artifacts and the resolution of vessel- and airway structures for each of the 228 lung segments in twelve volunteers were evaluated by two observers, judgement by consensus. Depending on the presence of artifacts, the image quality for each segment was judged as "good", "sufficient" or "not sufficient". For image review, we used a commercial work station (MagicView ${ }^{\mathrm{TM}}$, Siemens, Erlangen, Germany). In addition to the obligatory review of the source images in coronal orientation, we reviewed secondary reformations of images in transverse and sagittal planes using the multiplanar reformation mode of the workstation (MPR).

\section{Results}

The $20 \mathrm{~s}$ breath-hold time was tolerated by all subjects. Imaging times for the acquisition of 3 slabs ranged from 5 - 10 minutes.

The quality of images obtained with the 3D-GRE (VIBE) sequence was high. Lung vessels showed bright signal due to inflow-artifacts, a typical effect on gradient recalled echo sequences. Segmental and sub-segmental vessels ( $4^{\text {th }}$ to $5^{\text {th }}$ order) could be regularly identified in all parts of the lung without administration of contrast material. The signal intensity of these flow artifacts varied with velocity and direction of the flow towards the slab orientation. As a side-effect, pulmonary arteries and veins could be discriminated by differences in signal intensity on single images (Fig. 1). Although motion artifacts led to blurring of mediastinal structures next to the heart, the trachea and the bronchial tree were well delineated. The walls from main bronchi, lobar bronchi and segmental bronchi (bronchi of $3^{\text {rd }}$ order) could be identified in all subjects and in all parts of the lung. Even single cartilage rings of the trachea and main bronchi could be detected in some subjects (Fig. 1).

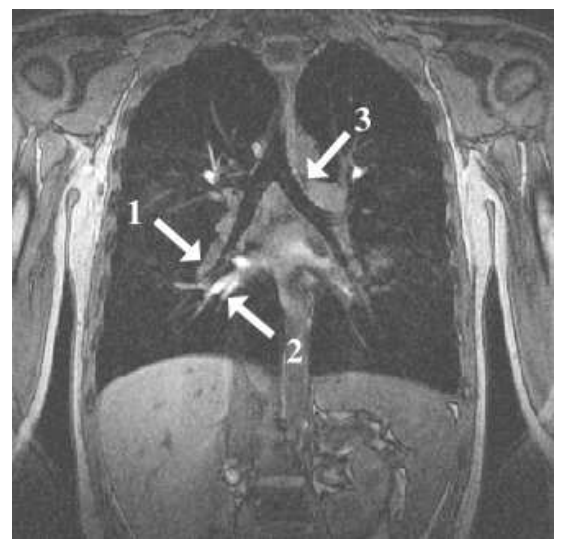

Fig. 1 Volumetric interpolated breath-hold 3D-GRE (VIBE) image in a 24 years old male volunteer. Clear delineation of the tracheal bifurcation and the hilar vasculature. NB: Different signal intensities of pulmonary arteries (1) and pulmonary veins (2) without the application of contrast material. Bright signal from cartilage rings of the left main bronchus (3). (coronal slice, TR $4.5 \mathrm{~ms}$, TE $1.9 \mathrm{~ms}$, FOV $400 \mathrm{~mm}$, Matrix $502 \times 512,2.5 \mathrm{~mm}$ slice thickness).

Secondary reformations were found to be particularly useful to detect small structures within the mediastinum. Reconstructed images in the axial plane reached a reasonable quality (Fig. 2).

Overall, the influence of motion and pulsation artifacts on image quality was moderate. Imaging quality was judged as "good" or "sufficient" in 224 of the 228 lung segments from twelve volunteers (146/228 "good"; 78/228 "sufficient"; 4/228 "not sufficient"). Ghosting artifacts related to cardiac and vessel pulsation predominated. These bright bands were most prominent next to the heart and the aorta, as the phaseencoding was orientated in right-left direction (Fig. 3). A significant contribution of breathing artifacts was not noted, as all volunteers tolerated the $20 \mathrm{~s}$ breath-hold periods. 


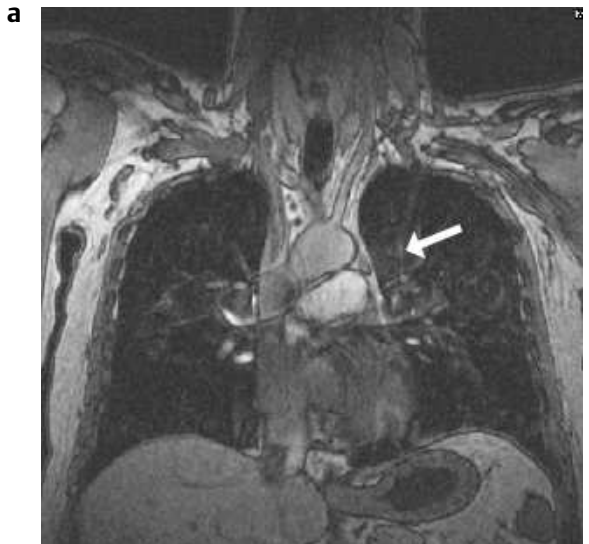

b

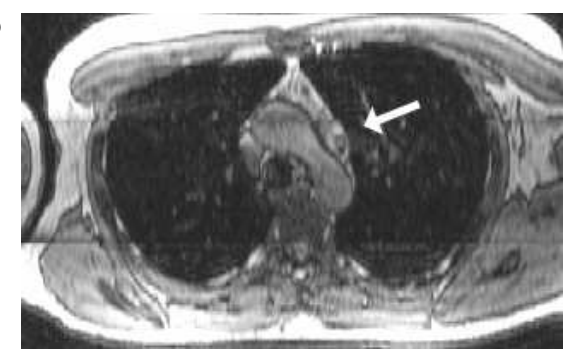

a

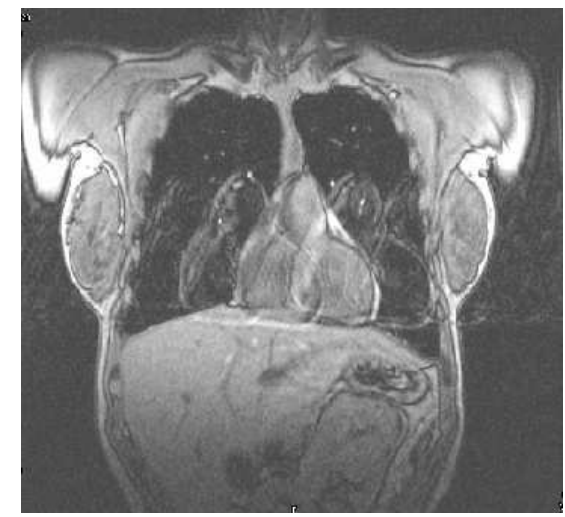

b

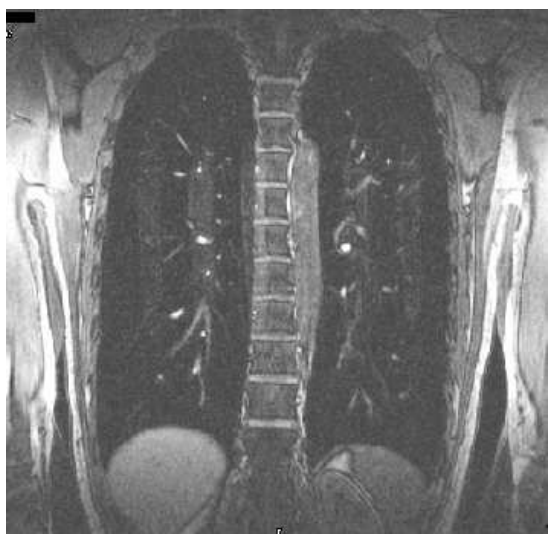

Fig. 2 Pre-aortic lymphnode of $8 \times 5 \times 4$ mm on a coronal primary image (a) and a secondary reconstructed axial slice (b) in a 32 years old male volunteer. Primary coronal images in 3D-GRE (VIBE) technique (TR/TE 4.5/1.9 ms, FOV $380 \mathrm{~mm}$, Matrix $502 \times 512,2.5 \mathrm{~mm}$ slice thickness).

Fig. 3 Moderate ghosting artifacts due to cardiac and vessel pulsation in a 23 years old female volunteer (coronal images in 3D-GRE (VIBE) technique, TR/TE 4.5/1.9 ms, FOV $400 \mathrm{~mm}$, Matrix $502 \times 512,2.5 \mathrm{~mm}$ slice thickness).

\section{Discussion}

The long acquisition times and a lower spatial resolution compared to CT are major problems in MR imaging of the lung. New detector techniques have boosted imaging speed and spatial resolution of helical CT, leaving MRI of lung morphology

and fine structure in a difficult situation [6]. Thus recent sequence developments have focused on functional aspects like ventilation or perfusion imaging and lesion characterization [2,7-12]. 3D-GRE (VIBE) sequences might open a new perspective for further developments in MR imaging of lung morphology.

3D-GRE sequences with short TR and TE were primarily developed for MR angiography using flip-angles of $20-60^{\circ}$ to pronounce the signal from blood after the application of T1shortening contrast material. 3D-GRE (VIBE) protocols use a similar sequence structure, but with lower flip-angles of $12^{\circ}-$ $15^{\circ}$ to enhance soft tissue signal. These sequences combine angiographic capabilities and a high spatial resolution with reasonable soft tissue contrast. The first application of 3D-GRE (VIBE) sequences was abdominal MRI. Liver studies with axial slices used a limited in-plane resolution with a matrix of $256 \times 256$ (interpolated from an initial matrix of $160 \times 160$ ) and included a quick fat saturation scheme [5]. Semelka et al. have noticed good qualities of these images for lower parts of the chest. Images from patients referred for abdominal MRI clearly delineated the mediastinum and the lower parts of the lung, as far as they were covered. These results already suggested, that a high imaging quality and negligible image artifacts could be expected [13].

Our protocol for imaging the lung uses nearly the highest inplane resolution of the sequence and thin slices to optimize spatial resolution. The slice thickness of $2.5 \mathrm{~mm}$ and the initial matrix of $251 \times 256(98 \%)(502 \times 512$ after volume interpolation) provide interpolated voxel sizes between $2.5 \times 0.70 \times 0.65$ $\mathrm{mm}^{3}$ (350 mm FOV) and $2.5 \times 0.9 \times 0.88 \mathrm{~mm}^{3}$ ( $450 \mathrm{~mm}$ FOV). A preliminary series of lung phantom studies confirmed best detection of small solid lesions within lung tissue at a flip angle of $12^{\circ}$ and with a slice thickness between 2 and $3 \mathrm{~mm}$. Slices thinner than $2 \mathrm{~mm}$ were not favorable, as the signal-to-noise ratio (SNR) decreased. The acceptable SNR of small voxels seems to be an obvious advantage of 3D-GRE (VIBE) sequences. Rofsky et al. described an inherent improvement of SNR in volumetric interpolated techniques due to filtering procedures [5]. However, using a fast 2D-GRE sequence with short TE, the reduction of SNR would have inhibited the use of very thin sections [2-4]. As a concession to the high spatial resolution of our 3D-GRE (VIBE) protocol, the slab thickness is limited to $80 \mathrm{~mm}$ and completion of the study requires the addition of three slabs.

The feasibility of the 3D-GRE (VIBE) imaging protocol could be demonstrated in twelve healthy subjects. The sequence provided good images of lung vasculature and segmentation without administration of contrast material. Small vessels were clearly detected due to their bright flow signal. As a side-effect, we noted different signal intensities of pulmonary arteries and veins on coronal slices. This is particularly interesting, as the overlay of pulmonary arteries and veins impairs the discrimination between the two vessel systems in contrast material studies [7-9,14]. The tracheo-bronchial system was also well depicted with delineation of bronchial walls up to the $3^{\text {rd }}$ order. This clear delineation of small lung structure details on 3D-GRE (VIBE) images reflects good qualities of image data processing. In particular, partial volume effects decrease with zero filling interpolation, like it was described for 3D-GRE sequences used in MR-angiography $[5,16]$. 
The overall imaging quality was at least comparable to 2D-GRE studies of the lung $[2-4,16]$. Ghosting artifacts from cardiac and vessel pulsation, which are generally very strong on coronal 2D-GRE images, were absent or only moderate on our 3D-GRE (VIBE) series $[13,16]$. Pre-saturation pulses to suppress the influence from moving mediastinal structures - sometimes used for 2D-GRE protocols requiring additional imaging time [16] - were not necessary. The 3D-GRE (VIBE) protocol can be obviously applied without cardiac or respiratory triggering in sufficiently cooperative subjects, as breath-hold imaging minimizes artifacts from respiratory motion [16,17]. It remains difficult to estimate, how far the still present pulsation artifacts would influence the diagnostic value of the sequence in patients, e.g. for detecting small lesions. As a possible solution, the sequence protocol includes optional cardiac triggering. It was successfully tested in two subjects, but not used for the present series (data not shown).

The possible clinical benefits of the 3D-GRE (VIBE) sequence protocol can be only estimated at this stage. The present study evaluated the sequence in healthy subjects and at standardized conditions. More difficult conditions are encountered in patients, i.e. subjects in respiratory distress. Thinner slabs of $40 \mathrm{~mm}$ (eight partitions) have to be tailored to keep within breath-hold time frames of 10 seconds or less. Multiplanar reformations (MPR) will be more difficult to perform, if the deepness of inspiration varies between the acquisitions. A sufficient overlap of the imaging volumes would be needed to avoid missing small lesions at the slab limits. Future hardware upgrades allowing for the acquisition of thicker slabs at
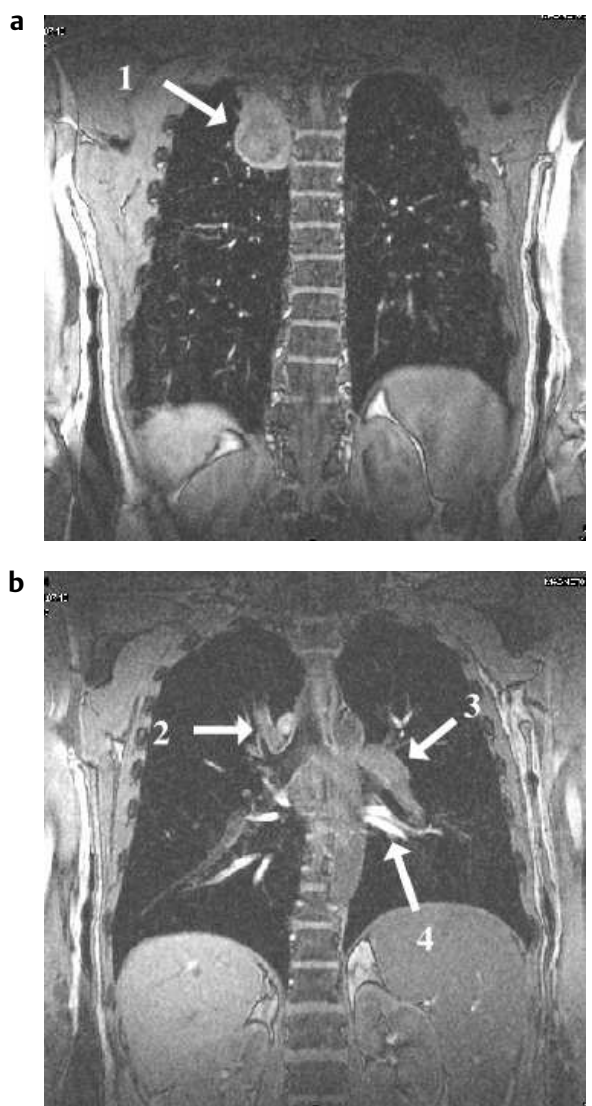

maximum spatial resolution and with reduced reconstruction times will contribute to overcome these problems. Although the first experiences are promising (Fig.4), larger patient studies including different lung pathologies and with CT correlation are required to prove the diagnostic accuracy of 3D-GRE (VIBE).

However, short acquisition time, high spatial resolution, good visualization of lung anatomy and a low rate of artifacts are clear advantages of the 3D-GRE (VIBE) sequence. We expect, that 3D-volumetric interpolated sequences with these qualities will soon replace the existing 2D-GRE strategies for MRI of the thorax. Future effort will have to focus on the further reduction of artifacts and on the clinical applications.

\section{References}

${ }^{1}$ Su S, Saunders JK, Smith ICP. Resolving Anatomical Details in Lung Parenchyma: Theory and Experiment for a Structurally and Magnetically Inhomogeneous Lung Imaging Model. Magn Reson Med 1995; 33: 760-765

${ }^{2}$ Hatabu H, Chen Q Stock KW, Gefter GB, Itoh H. Fast magnetic resonance imaging of the lung. Eur J Radiol 1999; 29: 114-132

${ }^{3}$ Alsop DC, Hatabu H, Bonnet M, Listerud J, Gefter W. Multi-Slice, Breathold Imaging of the Lung with Submillisecond Echo Times. Magn Reson Med 1995; 33: 678-682

${ }^{4}$ Moody AR, Bolton SC, Horsfield MA. Optimization of a Breat-Hold Magnetic resonance Gradient Echo Technique for the Detection of Interstitial Lung Disease. Invest Radiol 1995; 30: 730-737

${ }^{5}$ Rofsky NM, Lee FS, Laub G, Pollack MA, Krinsky GA, Thomasson D, Ambrosino MM, Weinreb JC. Abdominal MR imaging with a Volumetric Interpolated Breath-hold Examination. Radiology 1999; 212: $876-884$

${ }^{6}$ Thompson BH, Stanford W. MR imaging of pulmonary and mediastinal malignancies. Magn Reson Imaging Clin N Am 2000; 8: 729-739

${ }^{7}$ Böck JC, Pison U, Kaufmann F, Felix R. Gadolinium-DTPA-Polylysine-enhanced Pulmonary Time-of-Flight MR Angiography. J Magn Reson Imaging 1994; 4: 473-476

${ }^{8}$ Mai VM, Berr SS. MR Perfusion Imaging of Pulmonary Parenchyma Using Pulsed Arterial Spin Labeling Techniques: FAIRER and FAIR. J Magn Reson Imaging 1999; 9: 483-487

${ }^{9}$ Bremerich J, Roberts TPL, Wendland MF, Wyttenbach R, Arheden H, Reddy GP, Shafagi N, Higgins CB, Saeed M. Three-Dimensional MR Imaging of Pulmonary Vessels and Parenchyma With NC100150 Injection (Clariscan $^{\mathrm{TM}}$ ). J Magn Reson Imaging 2000; 11: $622-628$

${ }^{10}$ Amundsen T, Torheim G, Waage A, Bjermer L, Stehen PA, Haraldseth O. Perfusion Magnetic Resonance Imaging of the Lung: Characterization of Pneumonia and Chronic Obstructive Pulmonary Disease. A Feasibility Study. J Magn Reson Imaging 2000; 12 : 224-231

${ }^{11}$ Edelman RR, Hatabu H, Tadamura E, Potthumarthi WL, Prasad V. Noninvasive assessment of regional ventilation in the human lung using oxygen-enhanced magnetic resonance imaging. Nature Med 1996; 11: 1236-1239

${ }^{12}$ Biederer J, Reuter M, Winkler C, Both M, Richter C, Schnabel A, Gross W-L, Heller M. MR-Tomographie der Lunge bei Wegenerscher Granulomatose. Fortschr Röntgenstr 2001; 173: S32

${ }^{13}$ Semelka RC, Cem Balci N, Wilber KP, Fisher LL, Brown MA, GomezCaminero A, Molina PL. Breath-hold 3D gradient-echo MR imaging of the lung parenchyma: Evaluation of reproducibility of image quality in normals and preliminary observations in patients with disease. J Magn Reson Imaging 2000; 11: 195-200 
${ }^{14}$ Pielleul F, Naeem Merchant. MRI of the pulmonary veins: Comparison between 3D MR angiography and T1-weighted spin echo. J Comput Assist Tomogr 2000; 24: 683-687

15 Du YP, Parker DL, Davis WL, Cao G. Reduction of partial-volume artifacts with zero-filled interpolation in three-dimensional MR angiography. J Magn Reson Imaging 1994; 4: 733 - 741

${ }^{16}$ Biederer J, Reuter M, Steffens J-C, Schnabel A, Gross W-L, Heller M. MRT der Lunge mit T1-gewichteten Gradientenecho- und T2gewichteten TSE-Sequenzen - Untersuchung gesunder Probanden und Vorstellung klinischer Fallbeispiele mit CT-Korrelation. Fortschr Röntgenstr 2000; 172: S15

${ }^{17}$ Leutner C, Gieseke J, Lutterbey G, Kuhl CK, Flacke S, Glasmacher A, Theisen A, Wardelmann E, Grohe C, Schild HH. MRT versus CT in der Diagnostik von Pneumonien: Evaluation einer T2-gewichteten ultraschnellen Turbo-Spin-Echo-Sequenz (UTSE). Fortschr Röntgenstr 1999; 170: 449-456

Dr. med. Jürgen Biederer

Klinik für Diagnostische Radiologie

Universitätsklinikum Kiel

Arnold-Heller-Straße 9

24105 Kiel 1

Tel. $0431-597-3153$

Fax 0431 - 597-3151

E-mail: juergen.biederer@rad.uni-kiel.de

\section{BUCHBESPRECHUNG}

E. K. Fishman, R. B. Jeffrey: Spiral-CT. Prinzipien, Techniken und klinische Anwendungen. 2. Aufl. 2000, 418 S., 565 Abb., 40 farbige Abb., geb., 298,- DM, Georg Thieme Verlag, Stuttgart · New York. ISBN 3-13-124922-6

Das „Schneller - höher - weiter“ der Spiral-CT (schnellere Scanzeiten, höhere Kontrastausbeute, Weiterverarbeitung als 3D-Datensätze) hat der Computertomographie eine rasante Entwicklung neuer bildgebender Möglichkeiten beschert. So sahen sich die Autoren dieses amerikanischen Bestsellers, der erst 1998 im Original erschienen war, gezwungen, bereits nach 2 Jahren eine völlig überarbeitete 2 . Auflage herauszubringen, die jetzt in der Reihe „US-American Radiology Toolbooks“ auch in deutscher Übersetzung erhältlich ist. Leider berücksichtigt aber auch die Neuauflage nicht die Mehrzeilen-Detektortechnik, deren Einzug auch in Deutschland bereits begonnen hat und die einen weiteren Meilenstein in der CT-Diagnostik darstellen wird. Im übrigen wird jedoch die Technik der SpiralCT und insbesondere ihre klinische Anwendung umfassend und gut verständlich dargelegt. CT-Basiswissen wird hierbei jedoch zum Teil vorausgesetzt. In gesonderten Kapiteln werden insbesondere auch die CT-Angiographie sowie die neuen Techniken der Bildnachverarbeitung berücksichtigt. Hierbei wird nicht nur auf die Möglichkeiten von multiplanaren Rekonstruktionen, Maximum-Intensitäts-Projektionen, 3DOberflächendarstellungen, Volume Rendering und virtuelle Endoskopien eingegangen, auch deren Nachteile und mögliche Fehlerquellen werden diskutiert. In organbezogenen Kapiteln wird ausführlich und gemäß dem aktuellen Stand der Literatur auch die klinische Anwendung der Spiral-CT ausgeführt, sowohl im Hinblick auf geeignete Untersuchungsprotokolle als auch bezüglich der typischen diagnostischen Befunde bei den jeweiligen Erkrankungen. Diese Kapitel beschränken sich etwas exemplarisch auf die Organe des Thorax und des Abdomens. Das zugehörige Bildmaterial ist jedoch umfassend und hochwertig. Jedes Kapitel ist von unterschiedlichen und besonders erfahrenen Autoren geschrieben; dieses garantiert besondere Qualität, führt aber auch zu einer gewissen Redundanz. So findet sich z. B. in den verschiedensten Kapiteln aufs Neue eine Definition des Pitch, leider auch in unterschiedlichen Varianten. Insgesamt ist jedoch dieses gut verständliche Lehrbuch sicherlich eine sinnvolle Anschaffung, insbesondere für Radiologen, die ihre Grundkenntnisse der inkrementellen CT im Hinblick auf die Möglichkeiten der Spiral-CT erweitern wollen. Für Neueinsteiger in die Materie stellt aber auch das im gleichen Verlag erschienene CT-Lehrbuch aus der „Referenzreihe Radiologie“ eine überlegenswerte Alternative dar. Weitere Überarbeitungen werden ohnehin in absehbarer Zeit erforderlich sein. Denn die Mehrzeilen-Spiral-CT wird endgültig das ehemalige Schichtbildverfahren in eine 3D-Volumenbildgebung mit beliebigen Rekonstruktionsebenen und Monitorbefundung überführen. 